\title{
SOME BIBLIOGRAPHICAL EVIDENCE CONCERNING RESTORATION ATTITUDES TOWARDS DRAMA
}

\author{
BY H. GRANT SAMPSON
}

Professor Sampson teaches English in Queen's University, Ontario

I T has been suggested that "printing always reflects the tendencies of its period in forms of art and aims in life" and that "we unconsciously govern our printing by the kind of life we approve." In exploring this thesis for the eighteenth century, Bronson has suggested that "between general histories of printing on the one hand and detailed accounts of presses, printers, and foundries on the other, one might be led to conclude that little has been done in the study of printing as a sociological record, or as a manifestation of artistic standards within the broader context of periods of culture." Granting the assumption that a correlation does exist between the facts of publication and the general attitudes of an age, it may be worthwhile to examine the conditions under which Restoration plays were printed to determine if any light is thereby shed upon contemporary attitudes towards the drama.

Our concern in this paper ${ }^{3}$ will be with the conditions under which Restoration drama was printed: the size of the issue, the shape of the book, the cost, the design, the workmanship — any bibliographical evidence which might contribute to our understanding of the process of publication and of the cultural values of the age reflected in the kind of book produced.

Although drama accounted for a small percentage of the entire volume of publication during the Restoration-Arber consoled himself with the thought that in spite of their gross indecency plays formed under $2 \%$ of the total English books of the time ${ }^{4}-\mathrm{a}$ substantial number of plays was published. Nicoll, registering all known

\footnotetext{
${ }^{1}$ Daniel Updike, Printing Types: Their History, Form and Use, and ed. (Cambridge, Mass., I95I), I, xii; xiii.

${ }^{2}$ Bernard Bronson, Printing as an Index of Taste in Eighteenth Century England (New York, 1958), p. 5 .

${ }^{3}$ The material in this article was originally presented to a meeting of the Botetourt Bibliographical Society in Williamsburg, Virginia, on I 3 May 1970.

${ }^{4}$ Edward Arber, Term Catalogues, ${ }_{1668-1709}$ A.D., III (London, 1906), vii.
} 
plays of the period, including those whose titles only have been recorded, lists over 600 separate works. ${ }^{5}$ And contemporary comment testifies to the regularity of the practice of printing plays which have been produced on stage; for example, Edward Howard, in the "Epistle" to The Usurper (I667) says that he reluctantly goes along with the practice, even though the printed text must necessarily omit much that he considers to be essential to the play:

Since the impression of plays is so much the practice of the age that few or none have been acted which fail to be display'd in print, where they seem to put on the greater formality of authors, while perhaps thus appearing divested of the life of action which gave no small varnish to their figures, they suffer a more severe correction from the reader: Notwithstanding which disadvantage, I have adventur'd to be companion in the impression of this poem.

The number of plays and the regularity of the practice alone would suggest that even during the Restoration a sizeable number of people showed interest in reading plays, although the number is substantially smaller than that for the following half-century, and the motivation for possessing copies of plays may have been different.

The design of these plays was most ordinary. They were never given the splendidly engraved Baroque title-pages used in the early part of the seventeenth century and continued in Bible printing by such items as John Baskett's Bible of 1715 ; and the publication in I673 by William Cademan of Elkanah Settle's successful The Empress of Morocco with six full-page engravings of the settings for the production is a unique occurrence. Ornamentation was almost wholly abandoned during the I670's. Between I667 and I675 the printer Thomas Newcomb confined ornamentation in play quartos to initial gatherings; a headpiece and initial or factotum on the recto of the second leaf; a headpiece on the first page of the preface; and a headpiece or initial decoration (but seldom both), on the first page of the text. After examining Newcomb's printing practices, William Miller has concluded that "after I675 he used even less ornamentation in his play quartos than he had before that date, reaching a point finally about 1679 when he omitted it altogether. In this conversion he was only following the practice of his fellow London printers, many of whom had been turning out ornamentless play quartos since the early i670's." And Miller adds, "In

${ }^{5}$ Allardyce Nicoll, A History of English Drama $\times 660-1900$, I, 4th ed. (Cambridge, 1967), Appendix C. 
attempting to identify the printers of unsigned quarto plays published in 1679 or thereafter for the next thirty years, the bibliographer finds a knowledge of printers' ornaments practically useless." ${ }^{\prime 2}$ This reduction and-finally-abandonment of ornamentation meant that the resulting simplicity required a sharp eye for the organization of white space - a characteristic which printers either did not possess or did not feel they needed to waste on the printing of plays. The spacing was likely to be awkward and showed no evidence of care for typographical design. In fact, the title-page for single plays followed a set pattern: the title, in upper and lower case; "a comedy" or "tragedy" in capitals; information telling where it was acted; the information "Written by ..." between two simple (and sometimes uneven) horizontal rules; towards the turn of the century it was not uncommon to find a few lines of verse, printed in italics, above a further horizontal rule, and then the imprint. The I 705 title-page of Cibber's The Careless Husband follows this pattern; yet when the seventh edition came out in $173 \mathrm{I}$, there was included a frontispiece engraving showing the famous steinkirk scene from Act $V$, scene $v$. By the end of the eighteenth century plays had earned the right to use as elaborate title-pages as those of other genres of literature. Cumberland's The West Indian (177I), for example, has a splendidly picturesque engraving. Indeed, from the I720's on, design played an important part in the printing of theatrical matter, as seen in the elaborate tickets designed by such men as Hogarth for a performance of Fielding's $A$ Mock Doctor.

From the evidence which typographical design affords, it would appear that during the Restoration no one felt that it was important to suit the physical appearance of a play to its contents. This failure cannot be wholly blamed upon the low state of printing, for however inadequate and unimaginative many of the books certainly were, the plays were singled out for a consistency of insensitivity and sloppiness which must have reached beyond the standards of a craft to some basic assumptions by the age itself. The pressure of hasty publication could not have been the sole reason behind the calibre of design.

It appears that plays during the Restoration were customarily published within a few months of their first performance. Nicoll

${ }^{6}$ C. William Miller, "Thomas Newcomb: A Restoration Printer's Ornament Stock," $S B$, III $(1950-51)$, 55 . 
estimates that it was within a period of two or three months, and likely within an even shorter period towards the end of the century. ${ }^{7}$ During the Elizabethan era it had been not unusual to withhold publication of a play in order to lure more people to the theatre. The motivation behind the hurried printing of Restoration plays may have been to catch the attention (and shilling) of the buying public while the production was still being talked about, and to provide a convenient record of what had been seen on stage. In other words, the printed play acted as something of a souvenir programme.

The exact number of copies of any single play published during the Restoration is difficult to determine. It seems that between 1250 and I 500 copies was the usual number for any work of literature. In I667 Milton signed an agreement with the printer Samuel Symons for the publication of Paradise Lost according to which Milton was to receive $\epsilon_{5}$ at the outset and a further $\epsilon_{I}$ when the impression of I,300 copies had been sold; he was to receive an additional $E_{5}$ for each of any further impressions. This type of arrangement seems to have been pretty standard. If we take a maximum issue of I 500 copies and Trevelyan's estimate of the population of London in I 700 as 674,000 , we discover that a single published play might be purchased by about $0.223 \%$ of the citizens. However, it is worth keeping in mind, as Todd points out, ${ }^{8}$ that since paper was expensive, accounting for about $40 \%$ of the cost on a small issue and about $60 \%$ on a larger one, it is likely that printers would prefer to underprint any work which was not an established classic rather than risk being stuck with a surplus. Just where the break-even point on a play might occur is extremely difficult to judge. Henry Oldenburg, first Secretary of the Royal Society and editor of its Transactions complained in I 665 that "of the first transactions he [the printer Richard Davis] had printed he had not vended above 300 ; and ... he fears there will be hardly so many as to repay the charge of paper and printing." The Transactions appeared in $4^{\circ}$, and usually ran to about I 6 pages, selling for between $6 \mathrm{~d}$. and Is. From this scrap of information one might guess that a printer needed to sell close to I, ooo copies of a play in order to hope to make any kind of profit. In the eighteenth

\footnotetext{
${ }^{7}$ Op. cit., II (Cambridge, 1955), 387.

${ }^{8}$ William Todd, "Bibliography and the Editorial Problem in the Eighteenth Century," $S B$, IV $(1951-52), 41-55$.
} 
century, when there was no limit to the number of copies of a single issue which could be run off, the number rose most interestingly; for example, on 24 August I 738, Woodfall printed 3,000 octavo copies of James Thomson's A gamemnon, plus Ioo on fine paper; four days later he apparently printed a further I,500 copies. ${ }^{9}$ Hugh Kelly's False Delicacy in I 768 sold 3,000 copies before $2: 00$ p.m. on the day of publication, and by the end of the season, the bookseller had disposed of IO,000 copies. It is unthinkable that any play received this extent of support by readers during the Restoration.

The price of plays cannot have been a major deterrent from their sale. Rostenberg has summed up the cost factor of books during this period:

Plays and satires of the Restoration sold at approximately a shilling. Baldwin charged one shilling, eight pence for The Fam'd Romance of the Grand Cyrus, while his propaganda tracts sold from six-pence to one shilling. Scott had charged the diplomat, Sir Joseph Williamson, fourteen shillings for the repair of eleven chained bindings. Two gallons of "oyle" cost Hooke five shillings in 1673 . Pepys at the same time paid "Mr. Rutland I Is. 6d. for one pair of silk stockings." Hooke acquired a Smyrna carpet for $\mathfrak{f}_{5.5}$., while Pepys incurred an expense of $\mathfrak{E}_{\mathbf{I}} 5$ for mourning cloth for his wife and himself. Books and tracts [she concludes] often averaged less than certain household essentials or an occasional trifling extravagance. ${ }^{10}$

Of course, the fire of 2-6 September I 666 had helped to raise the cost of books because the stocks of most stationers were burned. It is believed that $\hat{E}_{\mathrm{I}} 50,000$ worth of books were destroyed in one day. ${ }^{11}$ Writing in his Diary for 20 March of that year, Pepys noted, "It is strange how Rycaut's "Discourse of Turkey," which before the fire I was asked but $8 \mathrm{~s}$. for, there being all but twenty-two or thereabouts burned, I did now offer 20 s., and he demands 5 Os., and I think I shall give it him, though it be only as a monument of the fire."

The Term Catalogues, which commence just after the fire, record Is. as the standard price for a play. There are two exceptions; Hilary I 672 lists The Conquest of Granada at 2s., and Easter 1677 lists The Destruction of Jerusalem at 2s. Both these plays are, however, IO-act works-exactly double the length of a regular play. The

9 John Edwin Wells, "Thomson's Agamemnon and Edward and Eleanora-First Printings," RES, XVIII (1942), 478-86.

${ }^{10}$ Leona Rostenberg, Literary, Political, Scientific, Religious and Legal Publishing, Printing and Bookselling in England, r551-1700: Twelve Studies (New York, 1965), p. 426 .

${ }^{11}$ Ibid, p. 420 . 
price of Is. remains stable throughout most of the seventeenth century. But at the end of the century, the price of plays tended to rise. Nathanial Lee's The Rival Queens ( I699) cost I 8d., as did Bevill Higgins' The Generous Conqueror ( 1702 ). From that time on, I $8 \mathrm{~d}$. appears to have been the standard price.

Few other books during the Restoration are listed at Is., and these are slight in either the content or volume; for example, The Wits, or Sport upon Sport; Being a Collection of Several Drolls and Farces $\left(4^{\circ}\right.$, I673); Female Poems by Ephelia ( $8^{\circ}$, I679). A number of books were priced below plays, and these books were quite clearly designed for popular distribution or were of even slighter content: Youth's Tragedy: A Poem drawn up by way of Dialogue between Youth, the Devil, Wisdom, Time, Death, the Soul, the Nuncius; for the caution and direction of the Younger Sort $\left(4^{\circ}\right.$, I67I), 4d.; The Soul's Warfare, Comically digested into Scenes; Acted between the Soul and her Enemies: Wherein she cometh off Victrix, with an Evangelical Plaudit ( $\left.4^{\circ}, 1672\right), 6 \mathrm{~d}$; Gout Raptures $\left(8^{\circ}, 1676\right), 6 \mathrm{~d}$; Bacchanalia, or $A$ description of a drunken Club: $A$ Poem (F, I680), 6d. The standard price of Is. for a copy of a regular-length play during this period compares favourably with the stable prices of admission to the theatre: $4 \mathrm{~s}$. for the boxes, half a crown for the pit, I $8 \mathrm{p}$. for the middle gallery, and Is. for the upper gallery.

The price of books is, of course, directly related to size. And this brings us to our most intriguing information. Bronson has said that "it seems clear that the eighteenth century had a notion of correct relations between subject-matter and physical size," and has outlined the change which took place in the printing of plays:

As the [eighteenth] century runs, single plays are printed almost invariably in octavo. The reason, simple or complex, is by no means obvious, since in the seventeenth century with equal regularity plays were printed in quarto. The change in convention came quite punctually at the opening of the new century, if we except a few authors who had been established in an earlier decade. It seems to have evoked no comment at the time: as if a new class of play-readers had suddenly appeared, unmindful of custom but equally expectant of consistency. Such abrupt fractures of convention are baffling and fascinating. No apparent cause either political, social, or economic, will account easily for this one. Perhaps the universal consciousness of a secular anniversary begets at such times the frame of mind expressed by Dryden in his Secular Masque: 
'Tis well an old age is out,

And time to begin a new.

The century-mark, with its psychological overtones, may not be so artificial a division as some rational historians would insist. ${ }^{12}$

This summary introduces a number of interesting ideas which need to be examined somewhat more fully.

Quarto was certainly the standard size for single plays during the Restoration. In fact, quarto remained the standard size well into the eighteenth century. The plays listed in the Term Catalogues which were not published in quarto seem to have an immediately obvious explanation. The Imperial Tragedy: Written by a Gentleman for his own diversion and now made publick at the importunity of Friends (attributed by Langbaine to Sir William Killigrew ${ }^{13}$ ) was published in $\mathrm{I} 669$ in folio. But this work had apparently not been given a production in London, and so was regarded as literature rather than drama. Although two of Orrery's plays were published in $\mathrm{I} 669$ in folio, each had been acted in London. But these productions had occurred two years previously, and they were being published together in a single volume called Two New Tragedies. In I 672 folio was again used for plays by Davenant, but this was a Collected Works. Translations of Roman drama were issued in octavo. Thomas Rymer's The English Monarch also appeared in octavo in I690, but this was a reissue of the 1678 play entitled Edgar, which (in turn) seems never to have been acted. It seems, therefore, that quarto was the regular format for plays which had been recently produced and were closely associated with the theatre. Folio or (later in the century) octavo was used for plays which had a literary, as opposed to a theatrical, orientation. This is consonant with the publishing practices for poetry; for example, Paradise $R e$ gain'd was issued in octavo, as was Poems by Ben Johnson, Jr., and Poems by Nahum Tate.

It is also worthwhile to note that closet dramas-usually they were of a religious nature-did not follow the practice of actual drama, but were published in octavo; for example, John Dunton's The Visions of the Soul (1692), Robert Fleming's Monarchical Image (169I), George Lesley's Divine Dialogues ( I684), or Thomas Sherwin's Youth's Comedy of The Souls Tryals and Tri-

\footnotetext{
12 Op. cit., p. $11 ;$ p. 13.

${ }^{13}$ Gerard Langbaine, An Account of the English Dramatic Poets (London, 1691),
} p. 315 . 
umph (1680). An instructional play such as Samuel Shaw's Words Made Visible: Grammar and Rhetorick accommodated to the Lives and Manners of Men ( I 679) was also published in octavo.

The actual date for a change in the format of publishing single plays occurs just after the first decade of the eighteenth century. Interestingly, the year which reflects this change most noticeably is I 7 I4. In that year newly printed plays began appearing regularly in duodecimo, and this practice continued until the early 20's, when octavo became usual. A survey of key plays by Susannah Centlivre outlines this development:

The Perjur'd Husband (1700) $-4^{\circ}$

The Gamester (I705) $-4^{\circ}$

The Busie Body (I 7o9) $-4^{\circ}$

The Perplex'd Lovers ( I 7 I 2 ) $-4^{\circ}$

The Wonder ( I 7 I 4 ) - $12^{\circ}$

The Gotham Election (I7I5)- $12^{\circ}$

The Cruel Gift (17I7)-12

$A$ Bold Stroke for a Wife (1718) $-8^{\circ}$

The Artifice (1723) $-8^{\circ}$

$\begin{array}{ll}1737-12^{\circ} & \text { reprintings } \\ 1714-12^{\circ} & 1737-12^{\circ} \\ 1732-12^{\circ} & 1746-12^{\circ} \\ 1719-8^{\circ} & 1734-12^{\circ} \\ & \\ 1737-12^{\circ} & \\ 1734-12^{\circ} & 1736-12^{\circ} \\ 1719-12^{\circ} & 1724-12^{\circ} \\ 1735-12^{\circ} & 1736-12^{\circ}\end{array}$

The short bibliographical career of Benjamin Griffin yields similar evidence:

The Injured Virtue ( 1715$)-12^{\circ}$

Love in a Sack ( 17 I 5 ) - I $2^{\circ}$

The Humours of Purgatory (1 716$)-12^{\circ}$

The Masquerade ( 17 I 7 ) - $12^{\circ}$

Whig and Tory ( 1720$)-8^{\circ}$

During the period I 7 I4-I 720 , those new plays published in octavo were almost always ones which either had been unacted or were being published in the same volume with other works; for example, Anne Finch's Aristomenes ( I 7 I3) was included in Miscellany Poems, On Several Occasions, Written by a Lady. After I 720 , octavo certainly became the accepted size for newly printed plays. In other words, from this time on, the format of plays made them look like any other genre of literature. Ballad operas and divine poems, tragedies and satires, farces and political treatises all looked alike.

During this discussion I have tried to be careful in indicating that what I said applied to the first publication of new plays. Reprints follow a somewhat different pattern. Here we begin the same: reprints of plays during the Restoration were also in quarto. But 
then they jumped to duodecimo, and remained there for the rest of the century, except for special editions. The reprinting history of a couple of specific plays will most clearly indicate this pattern.

$\begin{array}{ll}\text { Dryden, All for Love: } & 1678-4^{\circ} \\ & 1692-4^{\circ} \\ & 1696-4^{\circ} \\ & 1703-4^{\circ} \\ & 1709-4^{\circ} \\ & 1728-12^{\circ} \\ & 1740-12^{\circ} \\ & 1676-4^{\circ} \\ & 1685-4^{\circ} \\ & 1692-4^{\circ} \\ \text { Dryden, Aurengzebe: } & 1694-4^{\circ} \\ & 1699-4^{\circ} \\ & 1704-4^{\circ} \\ & 1735-12^{\circ} \\ & 1676-4^{\circ} \\ & 1684-4^{\circ} \\ & 1693-4^{\circ} \\ & 1733-12^{\circ} \\ \text { Etherege, Man of Mode } & 1682-4^{\circ} \\ & 1692-4^{\circ} \\ & 1715-4^{\circ} \\ \text { Banks, Virtue Betray'd: } & 1727-12^{\circ} \\ & 1753-12^{\circ} \\ & 1777-12^{\circ} \\ & 1685-4^{\circ} \\ & 1693-4^{\circ} \\ & 1703-4^{\circ} \\ & 1724-12^{\circ} \\ & 1731-12^{\circ} \\ & 1735-12^{\circ}\end{array}$

This pattern can also be found in the format of collected plays; for example, Farquhar's Works were published by Bernard Lintott in I 7 I I in octavo. But the 4 th and 6 th editions of I7I 8 and I728 dropped to duodecimo. A glance at the reprintings of the plays by Mrs. Centilivre listed above indicates a similar pattern.

This rather complicated body of evidence can be summed up, I think, in a series of generalizations. From I660 to I 7 I4 both new single plays and reprints were published in quarto; this format marked them off from serious literature, which was usually issued in folio or octavo. From I 7 I4-I 720 single new plays were usually 
in duodecimo, a size frequently also used for works of literature; there were few reprintings of Restoration plays during this period, but both quarto and duodecimo sizes were used. From I 720 on through mid-century new plays were issued in octavo, reprints were usual in duodecimo. But by this time a curious reversal had taken place: whereas during the Resoration plays were regularly published in quarto, with octavo reserved for special or collected editions, in I 730 the Daily Post for Monday 9 March advertised "On Wednesday next will be publish'd Sophonisba [by James Thomson] . . . N.B., A small number is printed in $4^{\circ}$ on large paper, for the curious." ${ }^{14}$ In the same year a further edition was published in duodecimo.

The attitude of dramatists towards their printed texts is of significance to this study. They seem to have shown very little concern over the accuracy or literary merit of the printed version. As his modern editors point out, except in two instances (Nero and Sophonis $b a$ ) there is no evidence that Nathaniel Lee revised his work for editions after the first; consequently these later editions have no authority. In selecting a copy-text, therefore, this fact must be taken into account, and a similar situation exists for most other Restoration playwrights:

In general the first quartos provide a clear and sound text; the later seventeenth-century editions, actually reprints with printer or stationer corrections only, show a gradual degeneration; the eighteenth-century collected editions are significant only for the attempts made by the editors to rationalize and clarify the texts. ${ }^{15}$

But it is interesting to note, however, that when he had the opportunity to do so, Congreve did make a number of significant alterations for a collected edition of his Works, published in I 7 Io. Some of these later alterations were "due to his concession to the changing tastes as well as to the royal proclamations for reforming the abuses of the theatre. Some were due to his desire to provide a 'reading edition' of his whole work, which led him for example to divide his plays into acts and scenes in accordance with the classical and the French tradition, and to rewrite much of the verse of The Mourning Bride in a more regular fashion." "These changes involve an elimi-

${ }^{14}$ D. F. Foxon, "Oh! Sophonisba! Sophonisba! Oh!" SB, XII (1958), 204.

${ }^{15}$ T. B. Stroup and A. J. Cooke, Works of Nathaniel Lee, I (New Brunswick, 1955), 7 .

${ }^{16}$ Herbert Davis, ed., The Complete Plays of William Congreve (Chicago, 1967), p. v. 
nation of what might be taken as vulgar or blasphemous language, a fuller indication of characters' entrances, and an omission of some trivial or meaningless lines, as well as a correction of a number of grammatical and typographical errors which had resulted from the careless work done on the quartos.

It is quite apparent that these changes are the product of a different attitude to the drama. A play-text is no longer regarded as a convenient record of a theatrical performance, but as a work of literature in its own right. That some kind of change in attitude towards plays had occurred between the Restoration and the I730's is indicated by John Clarke who in I 73 I published an Essay upon Study which carefully draws up a list of worthwhile books for a gentleman's library. The early plays, he says, are "generally very indiscreetly and foolishly writ, in a way proper to recommend Vanity and Wickedness, rather than discredit them; have a strong tendency to corrupt and debauch the Mind with silly mischievous notions of Love and Honour, and other things relating to the Conduct of Life ... [They] should be very sparingly and warily meddled with, especially by young People." But by the end of the first quarter of the eighteenth century, however, the attitude expressed by Clarke was becoming less prevalent. Drama was being viewed as a vehicle for moral teaching and as a genre which was "literary" rather than "theatrical"; that is, its merits could be recognized in the reading and not by necessity in the playhouse. The sociological, economic, and moralistic forces that effected such a change about the time of the accession of George I are, of course, very difficult to explain, but some bibliographical evidence suggests that a change in the cultural attitude toward drama did occur and that it is important to recognize the theatrical context of the printed drama of the Restoration. 